\title{
The Riba Conundrum: The Ethical Appeal of Islamic Banking
}

\author{
Nico P Swartz ${ }^{1}$, Odirile Otto Itumeleng ${ }^{1}$, Wankie ${ }^{1}$, Anisha Jeelabdeen ${ }^{1} \&$ R. Kumar ${ }^{1}$ \\ ${ }^{1}$ University of Botswana, Gaborone, Botswana \\ Correspondence: Nico P Swartz, Dept of Law, Faculty of Social Science, University of Botswana, Private Bag \\ 00705. Gaborone, Botswana. E-mail: nico.swartz@mopipi.ub.bw
}

Received: September 24, 2012

Accepted: August 16, $2013 \quad$ Online Published: November 18, 2013

doi:10.5539/jms.v3n4p184

URL: http://dx.doi.org/10.5539/jms.v3n4p184

\begin{abstract}
The rule of Islam is simple: if you advance a loan, you are entitled to receive your capital only and nothing more. If you wish to secure profit you should enter into a partnership and become a shareholder. Prohibitions against interest are not peculiar to Islam. If we were to trace back through history, a number of examples of such prohibitions can be found in the early Greek, Roman and Rabinnical thought. As a consequence of the decline of the influence of the Catholic Church and the Jewish aphorism that the taking of interest from gentiles is a commendable practice, laws were subsequently drafted for legalizing interest transactions. As a result, industrial, financial and commercial power become concentrated in the hands of giant Western corporations and a worldwide dominance of capitalist imperialism followed. This practice has created widespread acceptance of the practice of charging interest (usury) and has dominated Western law and ethics for over a millennium. But, the Western or capitalist economic system has proven a failure in its quest for economic justice, which serves to benefit all in society, both the rich and the poor. In particular, capitalism is currently causing a terrifying scenario of making the rich richer and the poor poorer due to interest charges. The fundamental motivation for the paper is to examine whether an alternative banking or economic system could contribute in alleviating the global financial crisis we face. This alternative banking model is to rest on social justice. It is necessary to reassert that this banking system is based on the avoidance of all forms of financial exploitation and on having as its principal object the combined purpose of the creation of wealth and the alleviation of poverty.
\end{abstract}

Keywords: scholastici, riba, mutuum, contractus trinus, damnum emergens, shariáh, poverty, third world debt crisis, profit

\section{Objectives of This Research}

The research attempts to get to the core of the meaning of riba from religious and economic perspectives.

It strives to attain a wider consensus on the meaning of riba among scholars and policymakers.

The research discusses the pertinent issues of riba that many blame for the global financial turmoil.

It postulates an alternative to a capitalist or riba-based economy.

Finally, the study purports to achieve a point where people can have the choice of a life without riba.

\section{Core of the Meaning of Usury (Riba) from Religious and Economic Perspectives}

\subsection{Religious Perspectives}

\subsubsection{In Greek Thought}

Riba (usury), the original name for modern interest or a fixed return on investment was present in the early Greek, Roman and Rabbinical thought. Riba is the practice of taking interest on interest, which was easily manipulated by adding the unpaid interest to the unpaid capital and using the sum as the base for the next interest payment (Note 1). This taking of riba (any interest or fixed return) was treated as an offence against morals (Note 2).

In Greece, taking interest was a fact of life, while the legitimacy of interest taking was recognized throughout Greek history, opposition to it did exist. Until the $6^{\text {th }}$ century BC, insolvent debtors were obliged to place their bodies at the disposal of their creditors to work as slaves, to be sold in captivity, or even to be killed (Note 3).

Plato and Aristotle condemned the practice of riba. The former saw money as barren and therefore outlawed profit on loans (Note 4). The latter saw money as a necessary art, but he is of the opinion, that if it becomes the 
end of life, if it knows no bounds, and if it turns to unnatural practices to satisfy its excessive desires, then it is contrary to man's true good. Aristotle exerted that money was intended to be used in exchange, and not to increase at interest (Note 5).

The usurer, because of greed, attempts to make a profit from what is naturally sterile and purely a medium of exchange (Note 6).

\subsubsection{Romans}

In his Corpus Juris, Justinian (483-565 BC) forbade interest to rise higher than capital (Note 7). Theodosius has decreed in $386 \mathrm{BC}$ that usurers should pay a penalty of fourfold the amount of illegal interest that they had taken (Note 8).

In 347 BC, in Rome, a law reduced the interest rate: “... the rate of interest was cut in half (semiunciarum tantum ex unciario fenus factum) (Note 9). A similar law, the Lex Fluminia minus solvendi (271 BC) allowed borrowers to pay off their debts with money of reduced value, and the Lex Valeria allowed bankrupt debtors to satisfy their creditors by repaying one fourth of what they owed (Note 10).

The Romans began to adopt the long-standing Greek practice of one percent per month (12 percent a year) as the rate of interest on loans. This became the legal maximum in Rome in $51 \mathrm{BC}$ (Note 11).

\subsubsection{Rabinnical Thought}

In Old Testament times, permission to take interest from Gentiles remained. Some even saw it as a command: "Unto a foreigner thou mayest lend upon interest, but unto thy brother thou shalt not lend upon interest" (Note 12). According to this understanding, Jewish people could extract usury from foreigners, but not from each other (fellow Jews) (Note 13).

The prohibition against usury was one of those laws which concerned only members of the Jewish community. Rabbi Simeon ben Eleazar, was of the opinion that this prohibition should extent to foreigners as well. He praised the person who lends without interest and condemned those who refuse to do so. In the same vein, the Tosephia to Baba Mezi'a notes the promise of a reward to those who lend freely. Philo (c. 30 BC to 45 AD) forbade anyone to lend money on interest to a brother or sister (anyone of the same citizenship or nation). He reflects that a free gift is in a sense a loan that will be repaid by the recipient when times are better, without compulsion and with a willing heart. He wrote in his De Virtutibus: "For along with the capital, in place of interest which they determine not to accept, they receive a further bonus of the fairest and most precious things that human life has to give: mercy, neighbourliness, charity, magnanimity, a good report and good fame" (Note 14). Similarly, the Mekiliha on Exodus condemns everybody who takes part in usury (Note 15).

Usury is at times made equivalent to denying God. The Gemara of the Babylonian Talmud quotes Rabbi Jose as saying: "Come and see the blindness of those who lend at interest [...] So-and-so has denied the God of Israel. In almost the same words, the Gemara of the Jerusalem Talmud labels interest taking as a denial of Yahweh (Note 17).

In the text of the Jerusalem Talmud, usury is connected with idolatry, the most serious of sins (Note 18). In the opinion of the rabbis, usury was also equivalent to the shedding of blood (Note 19). The rabbis also equate usury to the selling of one's own daughter into slavery. The Gemara on Arakin records: "[...] a man should rather sell his daughter than borrow on usury" (Note 20). Considering usury (riba) equivalent to robbery, the rabbi's excluded the moneylender from being a witness or a judge (Note 21).

\section{Economic Perspectives}

\subsection{A Deviation from Religious Views - the Legalizing of Interest Transactions}

The practice of usury and interest reappeared notwithstanding the fact that the charging of usury and interest was initially condemned (see previous paragraph) by the three major religious denominations. These religious denominations subsequently give way for an economic dimension in which the charging of interest or usury come to be accept in contemporary money-lending transactions. Their views, regarding Christianity, may be based on the parable of the talents told by Christto consider interest generated by deposits in banks not only normal practice but even a commendable one (Note 22).

As a consequence, laws were drafted for legalizing interest transactions. Scholastic treatises allowed exceptions to the ban on usury by which a lender in a mutuum may receive some payment beyond the principal (Note 23). If one lends money to a merchant or anyone else, who makes profit out of it, it is argued, it cannot be unjust to draw a profit from it yourself. Human laws were therefore promulgated to permit usury, and its aim was to avoid 
interference with the "useful" activities of many persons (Note 24). For example, the Holy Office, allowed in $1830 \mathrm{AD}$, for interest to be lawfully taken for money lent to merchants who were in profitable trade (Note 25).

Creditors were allowed to receive compensation from defaulted debtors on two grounds: If a debtor failed to pay a loan on the stipulated day, the creditor might suffer loss. In that case, the just price of the loan must include some compensation for the loss. This additional payment was called "interest." Interest might also be claimed if the lender lost an opportunity for making profit, because the debtor did not return the loan in time. The creditor could lawfully draw usury in the name of interest (Note 26). For example, the poena detentori or mora imposed a penalty for late payment - after the specified date of maturity of the loan. But it must bear in mind that a tacit agreement to make late payment was usurious. (in fraudem usurarum). The second title was damnum emergens a compensation for damages or loss that the lender incurred after having made the loan: for example, from not having the money accessible in an emergency - a fire or storm that destroyed his barns or livestock. A third title, was the lucrum cessans, the lender's opportunity cost in the form of interesse, this was viewed as licit difference between the principal and repayment of a loan. This title justifies the exaction of a return beyond the principal. The final title was the venditio sub dubio - a device where a loan was cloak in a sales contract which specified future payment. In this agreement the amount of a loan was disguised by augmenting the stipulated principal to be repaid by the amount of the required interest payment (Note 27). For example, goods are received on a particular day and paid for at a later date. The creditor received a higher payment at the later date because the value of the goods sold had increased by the time of payment. The difference between the prices of the goods on the day of reception and at a future date was effectively interest on the loan. Such contracts were open to abuse by the unscrupulous. In my view credit sales at much higher prices are to be considered usurious (Note 28).

Another title, which shares the same sentiment of the above, was the theory of contractus trinus (triple contract), which made usury lawful in the name of interest (Note 29). The contractus trinus was a legal trick used by European merchants in the Middle Ages to allow borrowing at usury. It was a combination of three contracts, which together yielded a fixed rate of return from the outset. For example, person A might invest $\$ 100$ with person B for one year. A would then sell back to B the right to any profit over and above say $\$ 30$, for a fee of $\$ 15$ to be paid by B. Finally, A would insure her or himself against any loss of wealth by means of a third contract agreed upon with $\mathrm{B}$ at a cost to $\mathrm{A}$ of $\$ 5$. The result of these three simultaneously agreed upon contracts was an interest payment of $\$ 10$ on a loan of $\$ 100$ made by $A$ to $B$ (Note 30 ).

The justification for usury may run along the following lines: Money lending involves an element of risk and an element of time. For the time during which the lender has extended the loan, he/she is unable to invest his or her money in alternative endowment schemes. Interest charges seem therefore to be the only outcome for the risk undertaken by the lender.

\subsection{The Judaic Question}

As mentioned earlier a deduction can be derived from the fact that the emergence of interest in the West was probably triggered by the Judaic permission of allowing the taking of interest from Gentiles. Abarbanel, who represents the first known Jewish attempt at an economic theory towards capitalism in the $12^{\text {th }}$ century says: "There is nothing unworthy about interest per se, because it is proper that people should make profit out of their money, (wine and corn, and if someone wants money from someone else), why should the borrower not give the lender a certain amount of interest? Why should a farmer, for instance, who received so much wheat to sow his field, not give the lender 10 percent, if he is successful, as he usually would be? This is neither despicable nor contemptible. It is an ordinary business transaction and correct. Nobody is under obligation to gives his money away to somebody else, unless it be for the sake of charity [...]" (Note 31). On the basis of this assertion, it would be appropriate to give some compensation to the owner of capital (Note 32).

Even Canonists (who have opposed the taking of interest) agreed that one may pay up to 5 percent for lending money. Pope Alexander VI gave permission to the rulers of the state to allow the Jews to charge interest (Note 33).

According to Calvin, interest is only forbidden in so far as it is opposed to equity and charity, otherwise nous sommes frères, voire sans aucune. This formula would have eventually become the new spirit of capitalism (Note 34).

This justification of the concept of usurious lending in Judaism and the relaxation against the prohibition of interest by Scholastici (western theologians) caused the dilemma of usury (riba).

\section{Consensus among Scholars on the Meaning of Usury (Riba) and Interest}

Usury (riba) is identified in a general sense as the taking of more than was lent (Note 35). 


\subsection{Definition of Usury}

McLaughlin asserts that usura is derived from ab usu aera, usu aeris, usuera, usueri, usurea or usu rei. It means pecunia and usury therefore signifies not only money, but any kind of goods which man possesses (Note 36). McLaughlin cited Innocent IV, who is of the opinion that usury is gain owed or exacted from a contract of loan (Note 37). A more comprehensive definition, forwarded by Hostiensis reads that usury is whatever is in excess of the capital for the use of the thing lent when either there is an agreement or this intention present or even that which without either agreement or intention is exacted from the borrower (Note 38).

\subsection{Teaching of Usury in the Middle Ages}

Gratian has composed his Decretum (Decretum Gratianus) after 1140, which embodied all the ancient laws of the Church. In Distinctions XLVI and XLVII, of the Decretum, he forbids clerics to demand usury and stipulated that a perpetrator of this crime never be raised to orders. In the case where the perpetrator is already in orders, he then be deposed. Gratian formulates a synopsis of usury in his Concordia Discordantium Canonum: "To demand or receive or even to lend expecting to receive something above the capital is to be guilty of usury; usury may exist on money or anything else; one who receives usury is guilty of rapine and is just as culpable as a thief; the prohibition against usury holds for laymen as well as clerics but, when guilty, the latter will be more severely punished" (Note 39).

Gratian inspires canonists and as a result they compiled a document, the Corpus Juris Canonici. This document dated from the twelfth to the fourteenth centuries and touches on the question of usury (Note 40). At these periods, the Canonists were all concerned with the problems of usury, of banking, of contracts, and with all the aspects of the commercial life which has become an important fact of these times (Note 41).

According to McLaughlin, the Lateran Council of 1139, detested the avarice of usurers in both divine and human laws. He alleges further that the Council of Vienne of 1311-1312 asserted that the chief official in any community commit an offence against God, when he draw up or cause to draw up, statutes permitting usury to be charged (Note 42).

To lend for usury is a mortal sin as is theft (Note 43).

McLaughlin says Baldus mentions that there are three kinds of usury, namely quaedam sunt usurae punitoriae, quaedem recompensatoriae and quaedem lucratoriae. The first kind is allowed by divine and canon lawto be demanded as interesse on account of delayed payment. The second kind is also permitted up to a certain amount following the custom of the place which requires compensation by way of permutation rather than by way of penalty. This kind of usury is based on equity, which entails that by natural reason, one is to forbid to enrich himself at the expense of another (Note 44). The third kind is forbidden by divine law (Note 45). McLaughlin interprets these rules as to read that interesse is allowed on the loss which the creditor suffers and on the profit which the debtor has made (Note 46). On the question, why interesse is allowed and usury forbidden, Baldus answers that the intention is different. He alleges that in the case of usury, the creditor intends to be a usurer, to demand something on account of the loan. On the other hand, in the case of interesse, the creditor receives something on account of the loss suffered or the gain which the debtor has made (Note 47).

McLauglin contends that both parties stand to lose or gain in a loan at usury. According to him, the creditor may lose the capital itself (Note 48).

The Decretum of Gratian condemn usury as the receiving of more than the sum lent, not only of money but of anything in kind, wheat, wine or oil (Note 49). McLaughlin interprets, the phrase on usury "... more than the sum lent," as any excess demanded, though it be a small gift (Note 50). He means whatever is added to the capital, no matter by what name (Note 51), and or whenever more is required that was given (Note 52), we have usury. The condemnation posed in the Decretum of Gratian, alludes also to usury, for example, those who buy with the intention of selling at a higher price, who engage in any business for gain or who in any contract receive more than they give (Note 53). According to McLaughlin, the following contracts may be usurious: If I lend you ten pounds and a poor horse worth five pounds for six months and demand twenty pounds. This contract is made to avoid the name of usury unless the horse was really worth than what has been added to the sum loaned. Another example, if I sell goods worth twenty pounds for thirty pounds to be paid at a certain date, I am guilty of usury unless there is doubt as to the approximate value of the goods. Also if I buy and pay now for grain to be delivered at harvest time and the current price which I pay is much lower than that which will then be current, this contract may be usurious (Note 54).

McLaughlin is also of the opinion that a penalty for the late payment of a loan may also results in usury transactions (Note 55). 


\subsection{Consensus by Scholars}

According to McLaughlin, Canon law condemns as usury the taking of more than the principal even though the lender assumes the risk (Note 56). The Corpus Juris Canonici states that if one expects to receive in return more than the amount of the loan, he is a usurer (Note 57). Urban III regards someone as a usurer, who would not lend money unless he knew that he would receive more than the capital. He also regards one who refuses to grant an extension of time to one who is under oath to repay a debt on a certain day, a usurer. Both of these are guilty of the crime of usury on account of their intention (Note 58).

Pro-banking scholars believes the Medieval contentions of the Scholastici is anachronistic for the modern day banking and finance system. They inclined to forge disjunction between interest and usury and forward three caveats in favour of the differentiation between usury ( $r i b a)$ and interest:

(a) Riba means usury and as such interest, particularly bank interest, does not fall into the ambit of riba.

(b) Riba relates to loans contracted by the poor and the needy persons for consumption purposes, while interest constitutes reward on commercial, productive and profitable loans.

(c) Interest stands for reasonable rate of return, while riba represents an excessive, exorbitant and exploitative rate of interest.

These three features assert that interest is moderate, while ribais exorbitant and oppressive. In view of nominal interest, like bank interest, they opine that the latter may not be regarded as riba (usury). It run along the linethat the modern day scholar regards the term riba in Islam, to covers only "excessive" interest (Note 59). This grouping is therefore of the opinion that not all forms of interest are riba (usury), whereas another group is of the opinion that riba (usury) covers all forms of interest and not only "excessive" interest (Note 60). On the strength of the latter, Khurshid Ahmad submitted that the three premises are totally incorrect, theoretically inadmissible and empirically baseless. He reasons that there cannot be any economic or Shari'ah justification for confining riba to usury and excluding interest from its jurisdiction. He asserts that as far as economic analysis is concerned there is no technical difference between interest and usury. He further avers that when we look upon the phenomenon from the demand side of economic analysis or the supply side, the rationale develop in economic theory for interest and usury are the same. If it is a reward for waiting, there cannot be any differentiation between interest and usury (riba). Khurshid Ahmad alleges, if the question is examined from the productivity approach, there cannot be any differentiation between the two. Whatever differentiation has been introduced in the literature comes on moral grounds stating that one is high and exorbitant (usury) and the other is low and as such reasonable and secondly that usury deals with loans to the poor for consumption purposes, while interest deals with profitable commercial advances. According to Khurshid Ahmad there is no economic substance in any of these excuses (Note 62). There is no difference between consumption loan or production loan or high rate or low rate or loan taken by a poor person or rich (Note 63).

In view of the perception(s) of Khurshid and the general definition furnished above, the research shows a penchant for the opinion that there is no technical difference between interest and usury. The research can now vouch that there is consensus among scholars that the term covers all forms of interest and not only "excessive" interest (Note 64).

Since usury (riba) involves paying more than the value of money received, it offends against commutative justice in that it charges more than the value of the money lent, which is unjustified since money is barren and can produce nothing in and of itself. Usury (riba), therefore affects wealth transfer from the poor to the rich and is harmful to individuals and society (Note 65).

\section{Usury (riba) as Cause for the Global Financial Turmoil}

\subsection{Rationale for the Prohibition of Usury (Riba)}

The philosophical basis for the prohibition against usury (riba) dealt with the very nature of money itself. The Third Lateran Council, condemning usury in 1179, stated that many persons are deserting other occupations to become money lenders (Note 66).

If the taking of usury was allowed many evils would follow. People would neglect the cultivation of their lands. This would cause famines and the poor would perish. Though they might have lands to till, they would not have the animals and implements necessary because they have not their own, and the rich would place their money out at usury where the profit is greater and more certain, rather than in agriculture where the gain is smaller and less certain. Food would be so expensive on account of its scarcity that the poor would be unable to purchase it (Note $67)$. 
The paying of usury perennially will reduce men to poverty and one who practices usury can hardly avoid falling into the sin of idolatry: "The heart of the avaricious is in his money" (Note 68). For this reason, usury is against charity and piety since we are obliged to love our neighbor and succor him in need (Note 69).

No one could for long pay usury without being reduced to poverty (Note 70).

The diversion or aberration of "money" from its basic function as a medium of exchange is in my view the basis for the financial crisis. Money, is however, made as an object of trade, which transformed the whole economy into a balloon of debts over debts. This is what Imam Al-Ghazali had predicted 900 years ago when he insisted that money should not be taken as an object of trade. He remarked: "Riba (interest) is prohibited because it prevents people from undertaking real economic activities. This happens when somebody with money is allowed to earn more on the basis of interest [...] It becomes easy for him to earn more money on the basis of interest without exerting himself to real economic activities. This leads to hampering the real interest of humanity, because the interest of humanity cannot be safeguarded without real trade skills, industry and construction" (Note 71).

All this happened because money was allowed to be used as a machine producing more money on the basis of interest, and its function to act as a medium of exchange was left out of the equation. The aspect of interest has been criticized by many economists. For one, James Robertson writes; "The pervasive role of interest in the economic system results in the systematic transfer of money from those who have less to those who have more. Again, this transfer of resources from poor to rich has been made shockingly clear by the Third World debt crisis:" [...] It is partly because those who have more money to lend, get more in interest than those who have less; it is partly because the cost of interest repayments now forms a substantial element in the cost of all goods and services, and the necessary goods and services looms much larger in the finances of the rich. When we look at the money system that way and when we begin to think about how it should be redesigned to carry out its functions fairly and efficiently as part of an enabling and conserving economy, the arguments for an interest-free monetary system for the $21^{\text {st }}$ century seems to be very strong (Note 72).

\subsection{The Banking Sector}

Western banks lend excessively to augment their profits. They are assured of the repayment of their deposits with interest. This leads to an unhealthy expansion of credit, to excessive leverage, to even subprime debt and to living beyond means (Note 73).

Two factors enable Western banks to assume that they will not suffer losses. The first is collateral. If there is no risk-sharing, the bank will not always undertake a careful evaluation of the collateral and they may extend financing for any purpose, including speculation. The second factor that provides protection to banks is the "too big to fail' concept, which assures them that the central bank will bail them out. Banks equipped with such safety nets have incentives to take greater risks than what they otherwise would (Note 74).

The easy availability of credit makes it possible for the public sector to have high debt profiles and for the private sector to live beyond its means and to have high leverage. This leads to financial fragility and debt crisis. The easy availability of credit and the resultant steep rise in debt are the result of inadequate market discipline in the financial markets due to the absence of risk-sharing (Note 75). The prevailing financial crisis, which started in 2007, caused Western banks to have been bailed out of three to four trillion dollars by the US, UK, Europe and a number of other countries. The financial crisis has seized up money markets and has led to a precipitous decline in property and stock value, a rise in bank failure, and nervous anxiety about the fate of the global economy and the financial system. This created an uneasy feeling that there is something basically wrong with the Western interest-bearing banking system.

\section{An Alternative to a Western Interest-Based Model: Islamic Financial Architecture}

As the current economic crisis unfolded, it became evident that the international financial architecture is in need of reform. The crisis obliges us to re-plan our journey, to set ourselves new rules. This crisis becomes an opportunity for discernment in which to shape a new vision for the future. A system concerned only with interests, advantages and power calculations will not be able to create a world in which humanity is central. If global banking practices were based on Islamic principles, we would not be seeing the kind of crisis we are living through now.

In its very nature and as emphasize in this research, interest is a hindrance to the moral and material growth of the society. Money lenders who grab interest income appear to be motivated by greed, selfishness, narrow-mindedness, self-aggrandizement and malignancy. These negative qualities in society dilute the positive qualities related to charity (Note 76). In the Quran, Allah deprives usury (riba) of all blessings, but blesses 
charity (Note 77). The reason why the Quran is so strict about the levying of interest, is that Islam is against all forms of exploitation. Islam condemns, for example, all forms of exploitation, particularly injustice in the form of a lender being guaranteed a positive return without sharing the risk with the borrower. The borrower spends labour and time and utilizes his or her skills, but there is no guarantee of profit. In contrast, the money lender simply lends funds and does not invest time or labour in the business, but is guaranteed a fixed rate of profit in the form of interest. Interest charged on loans and advances therefore amounts to exploitation as the borrower is in a weaker position (Note 78).

There arise instances where the debtor has paid the original amount of a loan in full, but due to the accumulation of interest, the amount outstanding is more than the principal amount advanced. In Islam, money is only a medium of exchange. It has no value in itself. It should therefore not be allowed to give rise to more money via interest payments. Money advanced to a business as a loan, is regarded as a debt of the business and not capital and is therefore not entitled to any return (interest). Usury charges render the full adjustment of loans almost impossible, and the poor person continues taking one loan after the other to get out of the vicious circle without any success. The poor person has already paid much more than the original amount, but the outstanding amount continues to rise due to the application of usury (riba). This notion can be illustrated in the following story highlighted in the British media. David Taylor, a leukemia patient, had taken a loan from a major Western bank. The bank overdraft was growing at a frightening rate due to the bank's high interest rate. The poor and sick man was worried that the longer he lived, the more of his life assurance money would be taken by the bank, leaving little or nothing for his family. Every additional day of his life meant less money for his wife and children. He was, therefore, not interested in prolonging his life. This example explains the misery of the application of overcharging of loans. Islam thus determined that only the principal amount should be recovered on such loans provided the borrower is in a position to repay (Note 79). It is on this moral and economic logic that Islam prohibits usury $(r i b a)$ in all its forms and intent.

\subsection{Life without Usury (Riba)}

The interest-based economic society is tottering on the brink of disaster. It is in times like these that the phenemenon of the resurgence of Islamic banking is started to make its impact. Islam is not merely a spiritual formula but as a complete code of life in itself envisaging the economic well-being of an individual as well as a society upon sound foundations and divine instructions.

Islam does not stop at the moral condemnation of usury. It also reforms the character of a people so that an inclination to usurious businesses are suppressed and replaced by a spirit of sympathy and generous co-operation in human society.

As mentioned in the paper, in an usurious (capitalist) society, the individual is exploited. As a consequence, the chances of developing trade and industry diminish and opportunities for capital formation become scarce. The rise in the capital holdings of a few individuals will cause a depression in the collective economy. In a capitalist system, one individual enhances accumulated wealth in a way that renders thousands incapable of earning anything, let alone saving.

In contrast to this, in a society in which the interest is zero, the state guarantees relief to every citizen in need, and stinginess and hoarding of wealth will vanish. The affluent citizens will spend freely and pass on enough purchasing power to the poor citizens. This will promote trade and industry, which will open up more employment opportunities. The majority of the people will save because of enhanced income. This saving will not arise out of stinginess, apprehension, or greed, but will be the product of an economic system in which the affluent will still be left with much surplus wealth as they will not find any needy person to whom it may be denoted. It is evident that Islamic banking is based, on the one hand, on the avoidance of all forms of financial exploitation and, on the other hand, on the creation of wealth and the alleviation of poverty. Herein, the Islamic banking system could contribute to alleviating the global financial crisis which we face. The capitalist system has failed in achieving this social justice for which the Islamic system was tailored.

\subsection{Conclusion}

The study has achieved its aim in solving the riba conundrum. In view of this research there is now consensus that the term usury ( $r i b a)$ covers all forms of interest and not only "excessive" interest. If the global economy has to bear this economic reality or theory in mind, we would not be seeing the kind of finance crisis, we are living through now. The study also asserts that interest is a hindrance to the moral and material growth of society in which the individual is exploited. This notion is taboo in Islam as it morally condemns the taking of interest. In so doing, Islam reforms the character of a people so that an inclination to usurious businesses are suppressed 
and replaced by a spirit of sympathy and generous co-operation in human society. The research served as a landmark for social justice in Islamic finance and banking law.

\section{References}

Ahmad, K. (1994). Elimination of Riba: Concept and Problems. Lahore. Shirkat Press.

Anwar, M. (1987). Modelling Interest-free Economy. A Study in Macro-Economics and Development. International Institute of Islamic Thought. Washington D.C.

Aristophanes. (1971). Nubes 1286ff (Loeb translation). In Maloney (Ed.), Usury in Greek, Roman and Rabbinical Thought.

Aristotle. (1971). Politica 1.10.1258a-b (Jowett translation). In Maloney (Ed.), Usury in Greek, Roman and Rabbinical Thought.

Burke, J. (2009). Usury Redux: Notes on the Scholastic Analysis of Usury by John T. Noonan. Working paper no. 0901. Department of Economics. Ave Maria University.

Chapra, M. U. (2008). The Global Financial Crisis: Can Islamic Finance help Minimize the Severity and Frequency of such a Crisis in the Future. A Paper prepared for presentation at the Forum on the Global Financial Crisis to be held at the Islamic Development Bank.

Diwany. (2000). Islamic Bond isn’t Islamic. The Banker Middle East.

Fekete, A. E. (2004). The Principle of Capitalization of Incomes. Monetary Economics. Gold Standard Universty. Retrieved from http://www.marxists.org/subject/jewish/leon/ch3a.htm

Holy Bible. (1984). The International Version. International Bible Society.

Hostiensis. (1940). Summa de usuries. In McLaughlin (Ed.), The Teaching of the Canonists on Usury (XII, XIII and XIV Centuries). Pontifical Institute of Medieval Studies.

Institute of Policy Studies. (1994). Elimination of Riba from the Economy. Lahore. Shirkat Press.

Maloney, R. P. (1971). Usury in Greek, Roman and Rabbinical Thought. Traditio, New York: Fordham University Press.

McCall, B. M. (2008). Unprofitable Lending: Modern Credit Regulation and the Lost Theory of Usury (2008-2009). Cardoza Law Review, 30(2), 549-615.

McLaughlin, T. P. (1940). The Teaching of the Canonists on Usury (XII, XIII and XIV Century). Pontifical Institute of Medieval Studies.

Munro, J. H. (2009). The Medieval Origins of the "Financial Revolution": Usury, Rentes and Negotiability. Dept of Economics, University of Toronto. MPRA. 511.

Philo. (1971). De Virtutibus. In Maloney (Ed.), Usury in Greek, Roman and Rabbinical Thought.

Plato. (1971). Leges 5.742 (Loeb translation). In Maloney (Ed.), Usury in Greek, Roman and Rabbinical Thought.

Siddiqi, S. H. (1994). Islamic Banking: Genesis \& Rationale, Evaluation \& Review, Prospects \& Challenges. Karachi: Royal Book Company.

Stein. (1956). Interest taken by Jews from Gentiles. Journal of Semitic Studies. http://dx.doi.org/10.1093/jss/1.2.141

Swartz, N. P. (2009). The Prohibition of Usury (Riba). A Moral-Ethical Perspective of Islamic Financial and Banking Law: A Comparative Study between the Islamic and the Conventional Model. Shariah Journal, 17(2), 409-430.

Umar Ibrahim Vadillo. (2006). Fatwa on Banking and the Use of Interest Received on Bank Deposits 33.

Vessio, M. L. (2005). The Effects of the In Duplum Rule and Clause 103(5) of the National Credit Bill 2005 on Interest. Unpublished Master's Dissertation. Pretoria. University of Pretoria.

World Economic Forum. (2010). Usmani Post-Crisis Reforms: Some Points to Ponder.

\section{Notes}

Note 1. Aristophanes, Nubes 1286ff (Loeb translation). 
Note 2. Anwar Modelling Interest-free Economy (1987) 2.

Note 3. Maloney Usury in Greek, Roman and Rabbinical Thought (1971) 84.

Note 4. Plato, Leges 5.742 (Loeb translation). In Maloney (1971) 86.

Note 5. Aristotle, Politica 1.10.1258a-b (Jowett translation). In Maloney (1971) 87.

Note 6. Maloney Usury in Greek, Roman and Rabbinical Thought (1971) 95.

Note 7. Maloney Usury in Greek, Roman and Rabbinical Thought (1971) 95.

Note 8. Maloney Usury in Greek, Roman and Rabbinical Thought (1971) 94.

Note 9. Maloney Usury in Greek, Roman and Rabbinical Thought (1971) 90.

Note 10. Stein. "Interest taken by Jews from Gentiles" 1956 Journal of Semitic Studies 141.

Note 11. Maloney Usury in Greek, Roman and Rabbinical Thought (1971) 92.

Note 12. Stein Journal of Semitic Studies (1956) 141.

Note 13. Vessio The Effects of the In Duplum rule (2005) 9.

Note 14. Philo, De Virtutibus 14 82-83. In Maloney (1971) 98.

Note 15. Maloney Usury in Greek, Roman and Rabbinical Thought (1971) 101.

Note 16. Maloney Usury in Greek, Roman and Rabbinical Thought (1971) 103.

Note 17. Stein Journal of Semitic Studies 141.

Note 19. Stein Journal of Semitic Studies 141.

Note 20. Maloney Usury in Greek, Roman and Rabbinical Thought (1971) 105.

Note 21. Maloney Usury in Greek, Roman and Rabbinical Thought (1971) 106.

Note 22. The Holy Bible, International Version, Matthew 25: 14-30; Luke 19: 11-27.

Note 23. John H. Munro. 2002. The Medieval Origins of the "Financial Revolution:" Usury, Rentes and Negotiability. (2002). Online at http://mpra.ub.uni-muenchen.de/10925 MPRAPaper no.10925 posted 25 June 2009.

Note 24. Thomas Aquinas. Summa Theologiae 2-2, q. 78, a. 1.

Note 25. Siddiqi Islamic Banking (1994) 5.

Note 26. Anwar Modelling Interest-free Economy (1987) 3.

Note 27. Munro The Medieval Origins (2007) 511-12.

Note 28. Burke (2009) par: Opportunities cost inflation, and default risk in the Middle Ages.

Note 29. Fekete (2004) lecture 4: The triple contract. The contractus trinus contract was considered an admissible verse of credit which escaped proscription on grounds of the usury laws.

Note 30. Diwany "Islamic Bond isn't Islamic" (2000). The Banker Middle East. This article was originally published during Summer 2000 on www.islamic-finance.com. An abridged version was published in Banker Middle East during November 2002.

Note 31. Stein Journal of Semitic Studies 143.

Note 32. Stein Journal of Semitic Studies 153-4.

Note 33. Stein Journal of Semitic Studies 157.

Note 34. Stein Journal of Semitic Studies 161.

Note 35. McCall "Unprofitable Lending: Modern Credit Regulation and the Lost Theory of Usury" (2008-2009) Cardoza Law Review 559.

Note 36. McLaughlin The Teaching of the Canonists on Usury 98.

Note 37. Innocent IV, Commentaria on x.v.19.c.1: "Usura est lucrum mutuo pacto debitum vel exactum." In McLaughlin The Teaching of the Canonists on Usury 98.

Note 38. Hostiensis, Summa de usuries, n.1, fol. 372: "Quodcumque solutioni rei mutuatae accredit ipsius rei usus gratia pactione interposita, vel hac intentione habita in contractu, vel exactione habita post facto." In McLaughlin The Teaching of the Canonists on Usury 98. 
Note 39. Concordia discordantium canonum. Dictum before C.14, q. 3, c. 1: "Quod autem praeter summam emolumenta sectari sit usuras; after c. 4: Ecce evidenter ostenditur quod quicquid ultra sortem exigitur usura est; before q. 4, $c$.

Note 40. McLaughlin, T.P. The Teaching of the Canonists on Usury (XII, XIII and XIV Century). Pontifical Institute of Medieval Studies, vol. 81: 81-147: 81.

Note 41. McLaughlin The Teaching of the Canonists on Usury (XII, XIII and XIV Century) 81.

Note 42. McLaughlin The Teaching of the Canonists on Usury 84.

Note 43. McLaughlin cited Cinus on Cod. iv.32.24: "Audivi Dynum dicentem quod non quia usurae prohibitae sunt jure divino et jure canonico et civili et quia foenerare est mortale peccatum sicut rapere."

Note 44. McLaughlin cited Cod. iv.32.2: "Secundae usurae similiter sunt permissae usque ad congruum et honestum modum prout mos regionis expostulat quia potius recipiuntur loco permutationis quam loco poenae... Sunt enim hujusmodi usurae onerosae, non gratuitae, et fundantur in ratione naturali aequitate quae est quod quis non locupletur cum aliena jactura."

Note 45. Cod. iv.32.2.

Note 46. McLaughlin cited Cod. iv.32.2: "Interesse enim est licitum quocumque nomine nuncupatur, tam in damno quam in lucro."

Note 47. McLaughlin cited Cod. iv.32.2: "Sed quare poena est licita super interesse, secus in usura? Respondeo quia in usura constat de intentione quod intendat esse usurarius."

Note 48. McLaughlin The Teaching of the Canonists on Usury 94.

Note 49. C.14.q.3.c.1 as cited in McLaughlin The Teaching of the Canonists on Usury 95.

Note 50. McLaughlin The Teaching of the Canonists on Usury 95.

Note 51. C.14.q.3.c.1 cited in McLauglin The Teaching of the Canonists on Usury 95: "Quodcumque sorti accidit, et quodcumque velis ei nomen imponas."

Note 52. C.14.q.3.c.4 cited in McLaughlin The Teaching of the Canonists on Usury 85: "Ubi amplius requiritur quam quod datur."

Note 53. McLaughlin The Teaching of the Canonists on Usury 95.

Note 54. McLaughlin The Teaching of the Canonists on Usury 97.

Note 55. McLaughlin The Teaching of the Canonists on Usury 97.

Note 56. McLaughlin The Teaching of the Canonists on Usury 103.

Note 57. C.14.q.3.c.1: "Si feneraveris hominem, id est sit u mutuum dederis pecuniam tuam a quo plus quam dedisti expectes... fenerator es." In McLaughlin The Teaching of the Canonists on Usury 106.

Note 58. X.V.19.c.10: "Hujusmodi hominess pro intentione lucre quam habent... judicandi sunt male agree, et ad ea quae taliter sunt accepta restituenda, in animarum judicio efficaciter inducendi." In McLauglin The Teaching of the Canonists on Usury 106.

Note 59. Swartz, Nico P. The Prohibition of Usury (Riba). A Moral-Ethical Perspective of Islamic Financial and Banking Law: A Comparative Study between the Islamic and the Conventional Model. Shariah Journal, vol. 17, no. 2 (2009) 409-430: 415-6.

Note 60. Swartz A Moral-Ethical Perspective of Islamic Financial and Banking Law 415.

Note 61. Institute of Policy Studies Elimination of Riba from the Economy 38.

Note 63. Institute of Policy Studies Elimination of Riba from the Economy 39.

Note 64. Vadillo Fatwa on Banking (2006) 34.

Note 65. McCall Cardoza Law Review 569.

Note 66. McLauglin Pontifical Institute iii.

Note 67. McLauglin Pontifical Institute iii.

Note 68.McLauglin Pontifical Institute iii.

Note 69. McLauglin Pontifical Institute iii. 
Note 70. McLauglin Pontifical Institute iii.

Note 71. Usmani Post-Crisis Reforms: Some Points to Ponder (2010) 19-20. In World Economic Forum.

Note 72. Usmani Post-Crisis Reform (2010) 19-20.

Note 73. Chapra The Global Financial Crisis (2008) 4.

Note 74. Chapra The Global Financial Crisis (2008) 4.

Note 75. Chapra The Global Financial Crisis (2008) 5.

Note 76. Ahmad Elimination of Riba (1994) 48.

Note 77. Holy Quran, Surah Al-Baqarah 2: 276.

Note 78. Siddiqi Islamic Banks (1994) 25.

Note 79. Siddiqi Islamic Banks (1994) 26.

\section{Copyrights}

Copyright for this article is retained by the author(s), with first publication rights granted to the journal.

This is an open-access article distributed under the terms and conditions of the Creative Commons Attribution license (http://creativecommons.org/licenses/by/3.0/). 